\title{
CINEMA AND SECOND LANGUAGE TEACHING
}

\section{Lorne Shirinian}

As a teacher of English as a second language at the advanced level and as a researcher in cinema theory, I have tried to introduce basic notions of cinema to my classes. Cinema is part of our everyday existence in North America. We come to understand film much in the same way as we learn to speak. Because of our constant exposure to films, much of this understanding of movies takes place unconsciously and builds from an early age. I have been asking my students to look at a specific series of films and to form critical judgements about them. The success of such an attempt depends on the maturity of the students, their intelligence, cultural background, exposure to cinema, and ability to control the target language.

As a beginning project I chose a film genre, the detective film, which deals with both private and police detectives. From a long list of possibilities, I came up with six appropriate films chosen because of their quality as cinematic art, variety of periods, locations and types of action, and availability of parallel literary texts. These were shown to first, second, and fourth year students at the Collège Militaire Royal in St. Jean, Québec. Most of the students at this college are highly motivated and, after first year, can function quite well in an English environment due to the bilingual atmosphere on campus. The francophone student population is quite homogeneous. As a result, the nature of their language learning difficulties is easier to focus on. Also, when preparing the students for the films, the teacher can anticipate vocabulary and syntactic problems. Using this technique in a situation where immigrants and/or refugees form a multi-racial, multi-ethnic group, greater preparation is needed. Individual teachers will have to decide if the use of such films is appropriate in their classes.

Detective films were chosen for many reasons. First of all they are interesting and usually appeal to students. The plots are often complicated and captivating, yet formulaic. Before long, the students are able to describe the formula and follow its variations from film to film. This maintains high student interest. The time span covered in the series outlined below ranges from 1941 to the future. The language is rich and varied, offering many avenues to exploit. Finally, the detective movie has a strong parallel history as a literary genre making it possible for the teacher to organize reading activities based on these texts in conjunction with the films. It is important to insist that the students see a series of these films. The movies become far more effective when planned as a progression. Using a series provides opportunities for students to compare and contrast characters, themes and plots. 
At some point, it is a good idea for the teacher to do some research on the subject. I spent some time reading detective novels and reviews as well as finding out about the history of the genre. I wrote an essay outlining the history of the detective novel and the place of "hardboiled" fiction in it. I then gave it to my students to read in class. We discussed the ideas presented in the paper in preparation for the viewing of the films and the reading of the detective stories. If you are interested in researching this topic further a filmography and bibliography appear in the appendix.

Three of the films studied were based on novels. I chose a number of scenes from these books for the students to read. The passages chosen either provided an interesting characterization or advanced the plot in some way. The students then went on to see these scenes in the films which allowed them to compare and contrast these two genres and express their opinions with regard to the quality of the film. In a fifteen week semester, it was impossible for my students to read all of these novels. Therefore, the students only read one novel in its entirety and were given excerpts from the others.

While reading the excerpts, the students learned a great deal of vocabulary including some colorful idioms. After introducing the new vocabulary from the text and the film, I gave the students a brief plot synopsis, trying not to give too much away. This synopsis was intended to help situate the students in this new world of detectives. The full length films were broken down into twenty minutes to one half hour showings viewed on consecutive days. The students were also given a sheet of questions they had to answer or prepare notes for during the film. These had to do with the actions, the characters, or film technique including camera position, editing, camera movement, and images. It need not get too complicated; however, I found that the students already had definite notions of film technique, and this provided them with the opportunity to state their opinions on these matters.

After the first film was seen, a class discussion took place based on the sheet of questions to confirm what the students thought or to clarify incorrect answers. I then brought to the students' attention any features I felt were necessary for their understanding of the film which had not yet been touched upon. At this time, the students were asked to pick out the main elements of the detective film they had just seen. This helped them to prepare for the next film in the series as well as construct a larger context for these films. For homework, the students would either answer the questions on the handout previously discussed in class or describe one of the main characters such as Sam Spade, the hero of "The Maltese Falcon."

The second film in the series was shown after an appropriate time lapse. The synopsis of the second film was read in class and new vocabulary was 
introduced. After an initial discussion, the students were encouraged to compare and contrast different aspects of the two films and the following questions were used to stimulate discussion. How is Phillip Marlowe in "The Big Sleep" different from Sam Spade? What qualities do they share? Are the points of view in the two films similar? The questions were also used as a starting point for writing activities.

This process was repeated until all six films had been reviewed by the students. As a final essay, a question asking them to discuss the character of the detective as seen in the films or asking them to describe the world of the detective helped put the films into final perspective.

After one complete trial, I have found the results encouraging. The students have learned a great deal of new vocabulary from authentic sources and have discovered a facet of North American culture through entertaining films and novels. In addition, by concentrating on one main theme it was possible for students to develop ideas in depth and make critical judgements. Finally, by participating in the activities described above, many of my students have learned to appreciate yet another art form.

\section{THE AUTHOR}

Lorne Shirinian was born in Toronto where he graduated from the University of Toronto with an Honours BA in French Language and Literature. He received his MA from Carleton in Comparative Literature and is now working on his doctorate in Comparative Literature at the Université de Montréal. He has published two books of poetry, the most recent of which is Poems of Dispersion and Other Rites of Movement, and a book of short stories, The Key and Other Stories. He lives in St. Jean, Québec, where he teaches English at the Collège Militaire Royal and is completing a new book of short stories. 


\section{APPENDIX}

\section{FILMOGRAPHY*}

"The Maltese Falcon," 1941

Directed by John Huston

"The Big Sleep," 1946

Directed by Howard Hawks.

"Chinatown," 1974

Directed by Roman Polanski.

"Bullitt," 1968

Directed by Peter Yates.

"Dirty Harry," 1971

Directed by Don Siegal.

"The Blade Runner," 1982

Directed by Ridley Scott.

\section{CORRESPONDING LITERARY} TEXTS

Hammett, Dashiell (1972). The Maltese falcon. New York: Vintage Books.

Chandler, Raymond (1976). The big sleep. New York: Vintage Books.

Dick, Phillip (1982). Do androids dream of electric sheep? New York: Del Ray Books.

*The films were shown chronologically in this order.

CRITICAL TEXTS ON DETECTIVE FICTION

Ball, J. (ed.) (1976). The mystery story. Harmondsworth: Penguin Books.

Cawelti, J. (1976). Adventure, mystery, and romance. Chicago: The University of Chicago Press.

Haycraft, H. (1983). The art of the mystery story. New York: Carroll \& Graff. Haycraft, H. (1978). Murder for pleasure. New York: Carroll \& Graff.

Kitteredge, W. \& Krauzer, S. (eds.) (1978). The great American detective. New York: Mentor Books.

Nevins, F. (1970). The mystery writer's art. Bowling Green: Bowling Green University Popular Press.

Penzler, O. (1977). The private lives of private eyes. New York: Grosset \& Dunlap.

\section{BIBLIOGRAPHY ON ASPECTS OF THE CINEMA}

Andrew, D.J. (1976). The major film theories. New York: Oxford University Press.

Andrew, D.J. (1984). Concepts in film theory. New York: Oxford University Press.

Evanson, W.K. (1972). The detective in film. Secaucus: Citadel Press.

Giannetti, L. (1982). Understanding movies. Englewood Cliffs: Prentice-Hall. Luhr, W. (1982). Raymond Chandler and film. New York: Ungar.

Mast, G. (1981). A short history of the movies. Indianapolis: Bobbs-Merrill.

Mast, G. \& Cohen, M. (eds.) (1985). Film theory and criticism. New York: Oxford University Press.

Monaco, J. (1981). How to read a film. New York: Oxford University Press. 